\title{
Same Content, Different Wrapping: Cross-Strait Policy Under DPP Rule
}

\section{Mikael Mattlin}

\section{(2) OpenEdition \\ 12 Journals}

\section{Electronic version}

URL: http://journals.openedition.org/chinaperspectives/436

DOI: 10.4000/chinaperspectives.436

ISSN: 1996-4617

\section{Publisher}

Centre d'étude français sur la Chine contemporaine

\section{Printed version}

Date of publication: 1 December 2004

ISSN: 2070-3449

Electronic reference

Mikael Mattlin, « Same Content, Different Wrapping: Cross-Strait Policy Under DPP Rule », China Perspectives [Online], 56 | november - december 2004, Online since 29 December 2008, connection on 28 October 2019. URL : http://journals.openedition.org/chinaperspectives/436 ; DOI : 10.4000/ chinaperspectives. 436

This text was automatically generated on 28 October 2019

(C) All rights reserved 


\title{
Same Content, Different Wrapping: Cross-Strait Policy Under DPP Rule
}

\author{
Mikael Mattlin
}

1 In the popular and especially Peking's view, there is a substantial difference between the Democratic Progressive Party (DPP) and the Kuomintang (KMT) with regard to their position on cross-Strait political relations. But how great is this difference in reality? These past four years of the DPP's first term in power provide us with the evidence of the DPP's cross-Strait policy in action, evidence that enables this comparison to be made. The first two years of Chen Shui-bian's first term as president saw a more conciliatory policy, which became a tougher approach starting in the late summer of 2002. On the whole the DPP's cross-Strait political relations diverged surprisingly little from a trajectory set already in the last years of KMT rule: of maintaining the ROC state in the face of increasing international isolation; the insistence on the position that Taiwan is an independent state; and frequent signalling of openness to talks with Peking as long as these did not include a "one China" policy as a precondition.

2 The article first briefly analyses the circumstances surrounding the election victory of Chen Shui-bian in 2000, compares KMT and DPP policies towards mainland China, and assesses the ups and downs of cross-Strait relations under the Chen presidency. It further identifies some structural constraints shaping the relationship and that foster a continuity of policy across regimes: Lee Teng-hui's "legacy people" in Chen Shui-bian's cross-Strait policy apparatus, the domestic political stalemate in Taiwan, and structural differences in policy-making in Taipei and Peking that make it difficult for the two parties to achieve agreement on anything substantial and tend to cause the positions to revert to one of no significant change. The article ends with a discussion of the changes that took place in cross-Strait politics with the change of administration.

The 2000 surprise change

Chen's victory in 2000 was in many ways premature. Many within the DPP had set their sights on the 2004 elections. Only a year before the elections it looked like Chen Shuibian, who had lost the Taipei mayoral elections in December 1998, would not stand a chance. But the soured relations between Lee Teng-hui and Soong Chu-yu came to a 
head, resulting in Soong leaving the KMT and running as an independent against partynominated Lien Chan, and as it turned out, sealing Chen's victory. The day after his victory at the DPP campaign headquarters, a campaign organiser-asked how they were going to handle the Peking relationship-said the campaign team had spent the whole night thinking about this particular issue as, not expecting to win, they had not really prepared for it in advance ${ }^{1}$.

The DPP came to power with an inexperienced team. Nowhere was this clearer than in cross-Strait policy-making. The new administration was forced to sift through academia and old KMT hands in its search for suitable talent that it could use. Even so, it was criticised for using many inexperienced young people. Much of the beginning of the term was therefore a mix of governing enthusiasm, naïve optimism and policy flipflops, as election promises met with realities of government.

Chen adopted a conciliatory tone towards Peking in his inaugural speech on May 20th 2000, saying that as long as Peking had no intention to use military force against Taiwan, he pledged that during his term of office he would not declare independence, not change the Taiwan's national title, not push ahead with the inclusion of the socalled "state-to-state" description in the constitution, and not promote a referendum to change the status quo with regard to the question of independence or unification. In addition, Chen pledged that the abolition of neither the National Reunification Council, nor the National Reunification Guidelines would become an issue ${ }^{2}$. On the other hand, the speech also contained some provocative rhetoric, such as the speech theme "Taiwan stands up"; an obvious play on Mao Zedong's famous words in $1949^{3}$.

6 The new administration's naïve optimism was abundantly clear with respect to its mainland policy, where it seems that many in the new administration genuinely believed that small goodwill gestures, such as opening up the so-called three small links, limited opening of travel for mainland businessmen, professionals and tourists to Taiwan, and significant toning down of independence rhetoric would induce Peking to return to the negotiation table ${ }^{4}$. The administration did not get the response it sought.

7 The shock at Chen's victory was evident in Peking. Few mainland scholars even considered Chen as being in the race for the presidency (at least publicly) ${ }^{5}$. Apparently only the Chinese National Security Bureau had the guts to predict that Chen might win $^{6}$. Nevertheless, in the public sphere Peking sensibly refrained from rash judgement, instead adopting a cautious policy towards the Chen administration. On the day of the election the Taiwan Affairs Office of the State Council announced that no matter who the new leader of Taiwan would be they would "listen to his words and watch his actions" (jiang ting qi yan, guan qi xing) to see in which direction he would take crossStrait relations ${ }^{7}$.

KMT and DPP formal cross-Strait policy

8 The KMT position on cross-Strait relations underwent considerable modification during the 1990s. The decade started with a substantial number of "Old Guard" mainlanders in leading positions within the party and an essentially unchanged mainland policy since the time of Chiang Kai-shek. In 1991 the KMT government dropped its claim to rule over all of China in the first of a series of six constitutional amendments. But the party still adhered to the idea of one China, although disagreeing with Peking over the interpretation of the concept, as evident in the supposed consensus revolving around "one China, with different interpretations" (yi ge Zhongguo gezi biaoshu) achieved in Hong Kong in 1992 as a preparation for the Singapore talks in 
1993. This consensus has, however, since been disputed in Taiwan by both the KMT government and the DPP8.

The Old Guard within the KMT grew increasingly uncomfortable with Lee Teng-hui's more obvious localisation policies in the early 1990s and finally left the party in 1993 to form the New Party. Mainland/Taiwan relations began to deteriorate after Lee Tenghui's visit to the United States and the missile rehearsals in 1995-96, and hit a low point in July 1999 when Lee Teng-hui talked about "special state-to-state" relations (teshu de guo yu guo guanxi) in a Deutsche Welle interview. The 1999 statement followed earlier similar but less provocative formulations. In 1997 the ROC government had already sharpened its stance by saying that one should talk about one divided China ${ }^{9}$, while through 1997-98 Lee Teng-hui several times mentioned that the ROC is an independent sovereign nation. The KMT's position on Taiwan's status seems to have moved with Lee Teng-hui's position during the 1990s towards more clearly emphasising Taiwan as a separate entity.

The DPP, on its part, has moderated its official stance on cross-Strait relations since the party charter of 1991, which contained a clause on working towards independence. On October 20th 2001, the DPP Party Congress decided to elevate a resolution (Taiwan qiantu jueyiwen) from May 8th 1999, to guiding line in its mainland policy ${ }^{10}$. The key point in the 1999 document is that the DPP already regards Taiwan as an independent, sovereign nation and therefore sees no need to declare independence. This could be construed as a moderation of the DPP's earlier position. The document also insisted that any change to this status quo would require the consent of the people through a referendum ${ }^{11}$. The new interpretation had been flouted publicly a year earlier in a seven-point statement by the DPP Central Standing Committee, apparently as a response to Clinton's visit to China and his so-called three no's statement ${ }^{12}$.

11 In August 2002 Chen Shui-bian used the characterisation "one country on each side" ( $y i$ bian yi guo) to describe cross-Strait relations. Chen's new concept and an earlier DPP document entitled Cross-century China Policy White Paper both echo Lee's state-to-state relations ${ }^{13}$. Thus, the two main political parties, having started the 1990s with radically different cross-Strait policies, ended the decade with substantially converged positions.

Peking, for its part, spelled out its Taiwan position perhaps most clearly in a White Paper ${ }^{14}$ published just before the 2000 election. It explains how Peking sees the dispute over Taiwan; why it regards Taiwan as belonging to itself; elaborates on the importance of the one China principle; and gives indications of what its bottom-line in the conflict might be.

13 The one China principle continues to be the cornerstone of Peking's stance on the Taiwan issue. However, Peking seems to have realised in recent years that it needs to show some flexibility on this. Consequently, it has tried to widen its definition of one China, most notably perhaps in a new formulation first mentioned by the former Chinese Foreign Minister Qian Qichen that "There is only one China in the world. Both the mainland and Taiwan belong to the same one China, and China's sovereignty and territorial integrity are inseparable" 15 .

The cross-Strait rollercoaster

14 The first two years of Chen's administration were a chequered story perhaps best characterised by such phrases as "haphazard", "fits and starts" and "damage control". Domestic politics quickly took over the agenda as one crisis followed the other, seemingly non-stop. Cross-Strait relations were of necessity put on a backburner and 
most cross-Strait initiatives during this time were small technical/administrative issues dealt with by the Mainland Affairs Council (MAC), such as opening the so-called three small links, preparation for the three big links, allowing mainland investments in some economic sectors, and gradual opening up of visits to Taiwan by mainland tourists, professionals and businessmen. Semi-official "soundings" continued through a handful of unofficial and semi-official envoys, such as Chen Chung-hsin a DPP legislator who heads the party's Mainland Affairs Department, and Hong Chi-chang-two of the few DPP people acceptable to Peking ${ }^{16}$. But apparently these came to naught as political positions still remained too far apart ${ }^{17}$.

Having finally regained its balance in domestic politics, the presidential office returned to the cross-Strait fray in August 2002. By the summer of 2002, the key actors in Taipei's cross-Strait policy-making were very disappointed at what they saw as Peking's failure to respond in a positive way to what they thought of as their own expressions of goodwill; a moderate inauguration speech by Chen in 2000, unilateral opening of the three small links and expressions of a willingness to talk about anything, as long as the one China principle was not a precondition for talks, to name a few ${ }^{18}$.

The Nauru-incident, when allegedly Nauru was bought off by Peking and switched political recognition was the apparent trigger for a rhetorical sharpening of Taipei's mainland policy. When even staunch unificationist Elmer Feng appeared content with Chen Shui-bian's cross-Strait policies, DPP insiders realised that it was time to take two steps back in order not to lose all political bargaining chips ${ }^{19}$. In quick succession Chen Shui-bian made several statements talking about "one country on each side" and about a possible defensive referendum, for the first time as a realistic option. This set the tone for cross-Strait relations for the latter two years of Chen's first term. Tensions between Taipei and Peking, simmering since July 1999, rose a few more notches following the inclusion of the word "Taiwan" on ROC passports, Chen's visit to the United States, and not least after Taiwan announced a "defensive referendum" in conjunction with the 2004 presidential election.

Peking was extremely unhappy about the referendum, which it saw as a ploy to take Taiwan one step further towards outright independence by introducing a procedure through which for example constitutional changes could be sanctioned ${ }^{20}$. The Communist leadership's trust in Chen Shui-bian, which had been low to begin with, fell to a nadir. But Peking refrained from repeating the mistake it had done during previous elections of coming with a direct and harsh warning to Taiwan voters just before the election, unless warnings to Hong Kong before Taiwan's presidential election are regarded as a veiled threat to Taiwan.

Taipei had, through the referendum, taken one step further away politically from Peking, but had fallen short of crossing the proverbial "red line", which is starting to look like a moving target. Peking, to its relief, found a face-saving exit in arguing that the fact that the referendum voter turnout did not exceed $50 \%$ showed that the Taiwanese people rejected Chen's policies ${ }^{21}$, and was not forced to act. "Watching his deeds, listening to his words" seems to have been taken rather literally in Peking.

Peking stuck to its cautiousness regarding public action after the election. The Taiwan Affairs Office issued a seven-point statement before the inauguration speech. The statement contained the usual vague and unspecific rhetorical threats and a diatribe about Chen having broken all the promises he made in 2000 and being untrustworthy. However, it also notably did not mention the "one country, two systems" policy, while 
it did adopt the new and slightly more flexible "one China" formulation in lieu of the "one China" principle ${ }^{22}$.

On the whole, the PRC government adopted a passive role towards Taiwan in Chen's first term. Whether this is a reflection of Peking being at a loss for options ${ }^{23}$, or having decided to let economic integration take care of the Taiwan problem, or just silence before the storm, is hard to tell. But whichever the case, the long-term trend towards Taiwan's clearer political separation from the mainland, which had started during Lee Teng-hui's years as president continued in a similar piecemeal pattern during Chen's first term.

Continuity in cross-Strait relations-structural determinants

There are a number of reasons for continuity in cross-Strait policy, many of them structural in nature ${ }^{24}$. One obvious source of policy continuity in Taipei is the simple fact that the DPP, short on talent in the cross-Strait policy-making area, made use of several people left over from the Lee Teng-hui administration ${ }^{25}$. Key cross-Strait policymaking insiders, who followed on to the next administration were for example Tsai Ing-wen, the MAC Chairperson in Chen's first administration, Chang Jung-feng, Deputy Secretary General of the National Security Council until the summer of 2003, Lin Chong-pin, who continued as vice-chairman of MAC and NSC member, and later became Deputy Minister of Defence, Wu Rong-yi, president of the Taiwan Institute of Economic Research (TIER), and Tien Hung-mao, one of Lee Teng-hui's policy advisors, who became the first Foreign Minister in the Chen government. The first two are commonly believed to be the "brains" behind Lee's 1999 state-to-state comments ${ }^{26}$. Chen also inherited Lee's military and security apparatuses almost intact. Not until some 15 months after taking office did Chen carry out a reshuffle of leading positions within the military/security apparatus, replacing several Lee Teng-hui loyalists with his own people ${ }^{27}$.

The marching order in Taiwan's cross-Strait policy-making was described by a highranking government official in an interview as the President-the National Security Council-the Executive Yuan-the MAC ${ }^{28}$. Since Chen's re-election, DPP stalwarts have taken over many key positions. Chiou I-jen returned to the post of Secretary-General of the National Security Council (NSC), while Parris Chang became Deputy Head of the National Security Council and DPP Legislator Chen Chung-hsin was appointed senior advisor to the NSC. Joseph Wu was appointed the new MAC Chairman, while former Taipei County Commissioner Su Tseng-chang now heads the Presidential office ${ }^{29}$. The new Foreign Minister Chen Tang-sun is known for his strong support for Taiwan's separate identity. Meanwhile, the current cabinet continues to be headed by Yu Shyikun, Chen's 2000 election campaign director and former DPP Secretary-General. The first cabinet was initially headed by Tang Fei, a former KMT Minister of Defence.

23 A second structural source of non-change in cross-Strait policy was the domestic political stalemate in Taiwan ${ }^{30}$. Although Chen might have wanted to move faster on several fronts, as anecdotal evidence suggests ${ }^{31}$, he was recurrently blocked by a Legislative Yuan he did not control. The legislative majority was in the hands of the "pan-blues" (WW, fan lan), who narrowly managed to retain the majority in the December 2001 Legislative Yuan elections. Even parts of Chen's own administration and party were unruly and obstructionist. The first two years often left the impression that Chen Shui-bian was charging ahead on his own, oblivious to his administration, party or the opposition. When this obviously did not work, Chen convened the so-called 
Economic Development Advisory Conference (EDAC) in the late summer of 2001 apparently in order to calm the turbulent political situation through this inclusive forum. Chen also introduced regular co-ordinating procedures between the presidential office, the DPP party headquarters and key DPP legislators in the summer of 2002 to at least bring his own "team" better on board" But the fundamental predicament remained: the Legislative Yuan was still in the hands of the pan-blues and major changes were therefore unlikely, unless they were in areas which the pan-blues would find hard to oppose due to popular support, like the Referendum Act that finally passed almost as a pan-blue drafted version in late $2003^{33}$, or the decision to halve the legislature ${ }^{34}$. Chen then found himself juggling with contradictory requirements from Peking, the opposition and not the least those of the DPP's "core" supporters who wanted to move more aggressively towards clearer independence. Chen's weak domestic position was naturally well known also on the mainland side ${ }^{35}$, and Peking was therefore reluctant to enter into any kind of political talks with Chen, instead hoping that Chen's administration would be only a temporary aberration.

Taipei's cross-Strait policy cannot be considered without paying attention to Peking's stance. A famous adage by Tip O'Neill says that all politics is local. There is no reason to doubt that this is the case also in mainland China and Taiwan. A Taiwanese expert on the PRC has argued that Taiwan's internal dynamics normally rank below China's domestic situation and the international environment (in particular relations to Washington) in determining Peking's Taiwan policy ${ }^{36}$. Similarly, much of Taiwan politics, including Taipei's cross-Strait policy, is affected by the island's recurrent elections. Taken together, these domestic constraints make cross-Strait "openings" difficult and likely to come to nothing, as the counterpart is usually unable to respond in the desired way, due to pressures from domestic audiences.

The PRC's Taiwan policy-making is structurally conservative. Scholars have argued that even though individual minds within the policy-making elite would be open to new ideas, several structural and procedural factors constrain creativity in decision-making and biases towards maintaining the existing policy line. Changing the basic position in any direction, but in particular as regards the one-China principle, becomes exceedingly difficult. For example, Jiang Zemin seemed unable to drop the idea of "one country, two systems", which tended to keep the formula afloat although it is obviously a stillborn idea in Taiwan ${ }^{37}$. Until recently, Jiang still retained a central role in Taiwan policy-making ${ }^{38}$. It remains to be seen whether Jiang's stepping down from chairing the Military Affairs Commission will bring more flexibility to Taiwan policy-making.

One scholar sees the lack of institutionalisation of PRC domestic politics and the vulnerability of the regime's legitimacy base as major sources of its inflexibility ${ }^{39}$. Whatever the reasons, the current cross-Strait policy-making apparatus in Peking could probably be described as cautious, deliberative and conservative, reflecting an over-arching need to maintain social and political stability. Major changes in policy are rare and thoroughly planned.

In comparison, Taipei's cross-Strait policy-making under Chen has been activist, impatient and somewhat haphazard, driven partly by a need to introduce new themes and tout policy "achievements" before every major election. Whereas we may hypothesise that Chiang Ching-kuo's administration probably worked more similarly to Peking's today and Lee Teng-hui's administration still retained elements of it due to the 
one-party legacy, Chen Shui-bian's administration so far has had a different style of working, starting from the president surrounding himself with thirty-something rising stars instead of a venerable gerontocracy, and being driven very much by opinion polls, media and election considerations, perhaps a bit like Clinton's administration.

To what extent Taipei's impatience is a reflection of Chen's personality is an open question. Close observers tend to describe Chen as a kind of impatient whirlwind who wants to get things done fast ${ }^{40}$. But one could also argue that it is a function of Taiwan's fast-paced political scene. Frequently, by the time Peking has come around to an official reaction to some event in Taipei, Taiwanese attention has already moved on to the next political show. For example, it took the Chinese state media until January 8th 2004 to offer an indirect reaction to the pan-blue camp's "surprise" endorsement of the Referendum Act in November $2003^{41}$, while it took almost two months for the Taiwan Affairs Office of the State Council and its counterpart within the Communist Party to come back with an official reaction to Chen's re-election ${ }^{42}$. In this sense, the mental gap between Peking and Taipei has grown in the past years. Of course, things are changing in Peking as well as younger leaders prefer less ritual and pomp and more tangible action. But there is still a gap and Peking genuinely seems to have a hard time understanding Chen Shui-bian.

These two machineries can perhaps be characterised as two trains moving at different speeds: Taipei's bullet train is charging ahead impatiently craving for tangible results, but by the time Peking's slower workhorse reaches the station, Taipei has already become frustrated and moved on to the next stop. The gap never closes and the frustration is mutual. To make matters worse, in cross-Strait policy it seems that Peking's preference is for clarity, whereas Taipei finds it has more room for manoeuvre the greater the obscurity. Chen Shui-bian talked vaguely about "integration" (tonghe) as a basis for cross-Strait relations early in his first term ${ }^{43}$, while recently he made an ambiguous reference to the Hong Kong 1992 meeting as a basis for discussions ${ }^{44}$. Peking has been far more consistent in insisting acceptance of "one China" is the only basis for talks and peaceful relations. Only the definition and formulation of "one China" has subtly evolved.

31 Thus, even if Chen Shui-bian initially set out to genuinely achieve a breakthrough in cross-Strait relations, this structural discord makes achieving any significant change inordinately difficult. Not surprisingly, Chen reverted to an earlier more confrontational position with regard to Peking and handling of cross-Strait relations. The structural constellation tends to push policy back to a gridlock, where both sides insist on the other side accepting preconditions for talks. At the beginning of his second term, Chen once more seems to be trying a more conciliatory approach. He will probably be frustrated again.

Changes: the subtle and not-so-subtle

We need however to point out that there are also a few notable areas of subtle and notso-subtle change in cross-Strait relations between the late Lee Teng-hui years and Chen Shui-bian's reign. One of the major areas of change concerns the state of trilateral communications and trust between Taipei, Peking and Washington. Another possible change concerns the clearer role Taipei has taken in setting the cross-Strait political agenda and therefore "driving" cross-Strait relations, if only by default.

33 A major problem in the current state of cross-Strait relations is a serious break in communication channels. Even semi-official communication channels between Taipei 
and Peking have been down since Lee Teng-hui's 1999 "state-to-state" comments. Before those statements, semi-official channels were open and relations cordial to the extent that envoys Koo Chen-fu and Wang Daohan were able to meet in Shanghai less than a year before. As noted above, during Chen's presidency, Taipei-Peking communication appears confined to the occasional messenger, a few private secret meetings, rhetorical shadow-boxing and occasional trial balloons.

At the same time, Taipei-Washington communication channels have also been troubled, to say the least, after Chen's coming to power. Chen's 2000 presidential election victory had been largely unexpected in Washington. As a consequence, there were few people in the United States who had good contacts with the DPP leaders or a good understanding of the party. Chen's perceived unpredictability has also generally lowered trust in him in Washington, even among traditional Taiwan supporters ${ }^{45}$. There is empirical evidence to suggest that Washington has not been well informed in advance of several of Chen's more controversial initiatives, such as the "one country on each side" statements and the referendum plan.

A pattern has already emerged: Chen makes a sudden controversial statement; Washington is astounded after which key officials in the Chen administration rush to Washington to explain Chen's intentions. Now, there is of course the possibility that this is only a show and that in reality Washington has been briefed in advance. But from Taipei having to back down and moderate the formulation of the referendum questions due to strong pressure from Washington to the seemingly genuine surprise and dismay of seasoned American Taiwan-watchers at some of Chen's actions, this appears unlikely. Needless to say, in the current state of heightened cross-Strait tensions, bad communication is a potentially dangerous added source of misunderstanding and miscalculation.

It has been common to regard cross-Strait relations as being decided on the axis between Peking and Washington. Certainly, Peking believes it can handle the problem directly with Washington without needing to talk to Taipei ${ }^{46}$. But this view fails to take into account that neither Washington nor Peking currently have either a clear consensus on how to handle Taiwan, or an interest in actively changing the situation. And neither does Taiwan, in an absolute sense. However, relatively speaking, one could argue that Taiwan currently actually has a stronger consensus on cross-Strait relations than either mainland China or the United States ${ }^{47}$; one revolving around maintaining the status quo. On the other hand, there is also a realisation in Taiwan that the status quo, if left unattended, will inevitably lead to slow absorption by China through unstoppable economic integration and a steadily squeezing international space. This provides a strong impetus for a more activist approach in Taipei among those who dread to see this happen.

It seems that Taipei has been pushing hard lately for the international community to confront the problem of Taiwan's international status, well aware that most other countries are now ready to turn their eyes away if Taiwan is absorbed by the PRC, due to China's greater economic importance. Chen has apparently purposely "pushed the envelope" repeatedly by making provocative statements or creating events that draw international attention to Taiwan. One such signal was the referendum organised in conjunction with the 2004 presidential election and the 2-28 mass rally accompanying $i^{48}$, which was seen as highly provocative both by Peking and by many in Taiwan. Another was the campaign for WHA observer status. Whether these actions have 
worked in the desired way or not is debatable. What they do seem to have done is snatch the cross-Strait steering wheel at least for the time being to Taipei. Talk of a new or revised Constitution by 2006 and earlier hints of a possible referendum on it ${ }^{49}$ is now setting the timetable for cross-Strait relations. A sense of urgency among the independence-minded in Taipei is creating an equal sense of urgency in Peking ${ }^{50}$. So, if only by default, the agenda for cross-Strait relations is now largely set in Taipei. A crisis is already scheduled for some time between 2006 and 2008.

of course, it is open to debate whether Taipei's increased activism in cross-Strait matters started with Chen Shui-bian. One could make a good case that a more activist role was taken already by Lee Teng-hui in his last years in office by an active "dollar diplomacy", frequent visits by the president abroad, several constitutional amendments and attempts to define a clearer separate status for Taiwan in speeches and writings. However, it is probably too simple to see Chen just as a disciple of Lee. Well-positioned observers tend to take the view that Chen's relations with Lee are respectful, but not particularly close ${ }^{51}$. Chen has continued on a road earlier travelled by Lee, but not necessarily because of Lee.

It is perhaps more appropriate then to see the major change in Taipei's cross-Strait policy as not one between two political parties' or two governments' policies/positions, but rather as a long-term gradual transformation spanning two decades and affecting the whole society. The gradual nature of this transformation should not obscure its magnitude.

More changes to come?

This brings us to a final caution on a conclusion. Although I have in this paper argued that in substantive terms there was not very much change in DPP and KMT cross-Strait policy between the first Chen and the last Lee terms in office, this does not mean that we can as yet draw such a conclusion for the entire Chen period. Chen Shui-bian was significantly hampered in his first term by his being a minority president without a majority in parliament and with an administration not entirely under his control. In the second term, he will be in a much better position to enact substantive changes. With $50 \%$ of voter support and a last term in office, Chen is domestically in a much better position to push through new policy initiatives. And although most observers seem to agree that he is primarily a tactician and not an ideologue, it does not mean that he does not want to leave without a legacy for his eight years in office.

41 In this context it is perhaps relevant to note that, while Chen's second inauguration speech on May 20th 2004 was generally greeted as conciliatory in tone, he notably did not mention the "five no's" directly. The "five no's" had been a key concession from the Taipei point of view towards Peking, and Peking had been relatively content with them $^{52}$. In their stead, Chen offered the sentence: "Today I would like to reaffirm the promises and principles set forth in my inaugural speech in 2000. Those commitments have been honoured-they have not changed over the past four years, nor will they change in the next four years" ${ }^{\prime 3}$. This is a suitably obscure sentence that can be interpreted either way.

Chen also slightly softened his call for a referendum on the new constitution by including the following lines in his inauguration speech regarding passage of the new Constitution: "Procedurally, we shall follow the rules set out in the existing Constitution and its amendments. Accordingly, after passage by the national legislature, members of the first and also the last Ad Hoc National Assembly will be 
elected and charged with the task of adopting the constitutional reform proposal as passed by the legislature, abolishing the National Assembly, and incorporating into the Constitution the people's right to referendum on constitutional revision. By so doing, we hope to lay a solid foundation for the long-term development of our constitutional democracy, and the people's right to referendum on legislative proposals for constitutional revision' ${ }^{54}$.

Again, the familiar pattern resurfaces: at snail's pace Taiwan edges towards clearer political separation from the mainland by taking full advantage of the grey and the obscure in politics.

Chen has already shown that he can play hardball with Peking. It appears that he is gearing up to formally cement the achievements of the localisation trend in Taiwan through a new Constitution. The circle closes. Chen Shui-bian appears to be following in Lee Teng-hui's footsteps also in the sense of revealing himself to be a bold political schemer.

\section{NOTES}

1. Interview with Lee Chun Yi, Taipei, March 19th 2000.

2. Chen Shui-bian inauguration speech, May 20th 2000, Taipei. Available at: http:// www.president.gov.tw/1_president/e_subject-043.html, accessed June 11th 2004.

3. Scholars have interpreted Mao's words as referring not to all Chinese people, but rather to those who were on the side of the revolution. Raisa Asikainen, "Nationalismin rakentaminen ja Kiinan ulkosuhteiden retoriikka”, Kosmopolis, No. 1, 2003, pp. 61-62. The same interpretation could be made of Chen's speech.

4. "Taiwan official says he expects breakthrough in cross-Strait ties", Taipei Times, January 31st 2001, p. 1.

5. Half a year before the presidential election, an expert on Taiwan's domestic politics at the Taiwan Research Centre (Tai yan suo) hardly even mentioned Chen Shui-bian when talking about the upcoming presidential election. Talk in Peking, September 1999.

6. Interview with a former policy advisor to the Chinese leadership, Hong Kong, April 2001.

7. Yang Lixian, "Chen Shuibian dangxuan yilai de Taiwan zhengju guancha", Taiwan yanjiu, Peking, No. 1, 2001, p. 19.

8. "Looking beneath the surface of the 'One China' question", Government Information Office, Executive Yuan, Republic of China, 1997. Available at: http://www.taipei.org/ whatsnew/onechina.htm, accessed June 11th 2004, and Lianhe bao (United Daily News), June 21st 2000.

9. Ibid.

10. Editorial, "DPP finally adjusts to new role", Taipei Times, Internet edition, October 22nd 2001, p. 8. 
11. Document available at: http://www.future-china.org.tw/links/plcy/dpp/ dpp19990509.htm, accessed July 19th 2004.

12. Yu Keli, Xie Yu and Dang Chaosheng, "Minjindang liang'an guanxi zhengce fazhan yanbian chutan”, Taiwan yanjiu, Peking, No. 2, 2001, p. 19.

13. Kua shiji Zhongguo zhengce baipishu, document available at: http://www.futurechina.org.tw/links/plcy/dpp/dpp19991115.htm, accessed July 19th 2004. See also Yan Anlin and Lu Xiaoyan, "Minjindang zhizheng yu haixia liang'an guanxi”, Taiwan yanjiu, Peking, No. 3, 2001, p. 38.

14. "The One-China Principle and the Taiwan Issue", White Paper released by the Taiwan Affairs Office and the Information Office of the State Council, February 21st 2000. Available at: http://taiwansecurity.org/IS/White-Paper-022100.htm, accessed June 10th 2004.

15. "Bush Push for Modified 'One China,' 'Integration”', The China Post, Internet edition, January 16th 2001.

16. "DPP said to be in secret China talks", Taipei Times, July 25th 2001, p. 1.

17. Interviews with two well-positioned legislative assistants in Taipei, August 2002, and two Lianhe bao journalists, Taipei, March 2004.

18. Interviews with a high-ranking official in the DPP government and a Gongshang shibao journalist, August 5th-9th, 2002.

19. Interviews with a senior DPP legislator, a Lianhe bao journalist and a Gongshang shibao journalist, August 5th-9th, 2002.

20. China Daily, Internet edition, November 29th 2003, p. 1. China Daily, Internet edition, January 8th 2004, p. 5.

21. "Taiwan 'referendum' vetoed by the people", China Daily, Internet edition, March 21st 2004.

22. "Zhongtaiban, Guotaiban shouquan jiu dangqian liang an guanxi fabiao shengming", Taiwan Affairs Office, May 17th 2004. Available at: <http:// www.gwytb.gov.cn/gzyw/gzyw1.asp?gzyw_m_id=359>. See also Lai I-chung, "Chinese leaders seek a flexible approach", Taipei Times, Internet edition, May 25th 2004, p. 8 for a well-informed Taiwanese interpretation of the statement.

23. A former policy advisor to the Chinese leadership suggested in an interview in Hong Kong, April 2001, that there was little that the Chinese leadership could do to rein in Chen Shui-bian, short of war.

24. Stefano Guzzini has provided an excellent conceptual analysis of structural power in international relations, which cautions us to the complexity of the phenomenon.

Stefano Guzzini, "Structural Power: The Limits of Neorealist Power Analysis", International Organization, Vol. 47, No. 3, Summer 1993, pp. 443-478.

25. Interviews with Lianhe bao and Gongshang shibao journalists, Taipei, August 5th-9th 2002.

26. Su Chi, “The undeclared 'special state-to-state' formulation: A year-end review of president Chen's Mainland policy", paper delivered at a conference sponsored by the National Policy Foundation, May 13th 2001, Taipei.

27. Editorial, “All the president's men," Taipei Times, Internet edition, August 10th 2001, p.12.

28. Interview in Taipei, August 9th 2002.

29. "Su Tseng-chang to take Presidential Office reins", Taipei Times, Internet edition, May 12th 2004, p. 1. 
30. Wu Yu-shan, "Taiwan in 2001: Stalemated on All Fronts", Asian Survey, Vol. 42, No. 1, Jan-Feb 2002, pp. 29-38.

31. "Chen's young 'scouts' learning quickly", Taipei Times, Internet edition, February 3rd 2004, p. 3.

32. Interviews in Taipei, August 5th-9th 2002.

33. "Legislature passes referendum law", Taipei Times, Internet edition, November 28th 2003, p. 1.

34. "Lawmakers take first step to cut legislature members to 113 seats", The China Post, August 24th 2004.

35. See e.g. Zhu Weidong and Xie Yu, “2000 nian Taiwan zhengju fazhan shuping”, Taiwan yanjiu, Peking, No. 1, 2001, pp. 24-29.

36. Lin Chong-pin, "Beijing's Agile Tactics on Taiwan”. Paper presented at the conference "The Political and Economic Reforms of Mainland China in a Changing Global Society". College of Social Sciences, National Taiwan University, Taipei, June 2002.

37. Mainland Affairs Council, "Public Opinion on Cross-Strait Relations in the Republic of China", available at: http://www.mac.gov.tw, accessed May 18th 2004.

38. Chu Yun-han, "Power transition and the making of Peking's policy towards Taiwan", The China Quarterly, Vol. 176, December 2003, pp. 960-980.

39. Hsu Szu-chien, “The Impact of the PRC's Domestic Politics on Cross-Strait Relations", Issues \& Studies, Vol. 38, No. 1, March 2002, pp. 130-164.

40. Interviews in Taipei with government official and a Lianhe bao senior political journalist, August 6th and 9th 2002.

41. "Pan-blue camp in Taiwan makes dangerous U-turn", The People's Daily, Internet edition, January 8th 2004.

42. See reference 21 .

43. "Chen urges China: Help, not hurt us", Taipei Times, January 1st 2001, p. 1.

44. "Chen seeks Cross-Strait code of conduct", The China Post, Internet edition, October 11 th 2004.

45. Conversations with Shelley Rigger in Taipei, August 2002 and March 2004.

46. E.g. “US, China Co-operate to Fight Taiwan Referendum Plan," The People's Daily, Internet edition, September 29th 2003.

47. This view is echoed by some Taiwan watchers. Author's conversation with JeanPierre Cabestan in Hong Kong, April 2001.

48. The referendum and 2-28 mass rally also had other functions. Their main function appears to have been election strategic.

49. "Taiwan to hold referendum on new constitution", Financial Times, Internet edition, November 11th 2003.

50. Interview with $\mathrm{Wu} Y u-s h a n$ in Taipei, April 2nd 2004.

51. Conversations with Timothy Wong in Hong Kong, April 2001, and an American official observing Taiwan politics, Taipei, August 2002.

52. See reference 21 and "Chen plays tricks in seeking independence", China Daily, Internet edition, May 26th 2004.

53. "President Chen's Inaugural Address 'Paving the Way for a Sustainable Taiwan'," May 20th 2004. Available at: <http://www.president.gov.tw/php-bin/prez/ showenews.php4>.

54. Ibid. 


\section{ABSTRACTS}

Surprisingly, cross-Strait political relations under Chen Shui-bian's first term as President (2000-2004) on the whole diverged little from the trajectory set in the last years of Kuomintang rule. This article analyses the reasons for this continuity. 